\title{
Copyrightability and formats of television shows under English law
}

Alexandros K. Antoniou, PhD, FHEA

University of Essex

School of Law

\section{Abstract}

The article discusses the High Court decision in Banner Universal Motion Pictures Ltd v Endemol Shine Group Ltd (Ch D) on whether the format for a television game show can be eligible for copyright protection under English law. It analyses the conditions required for the format of such shows to be classified as dramatic works and considers the importance of the decision for the media industry.

Keywords: copyright, format rights, television, dramatic works

\section{Background}

The case in Banner Universal Motion Pictures Ltd v Endemol Shine Group Ltd \& Anor ${ }^{1}$ related to a television game show format called Minute Winner, in which members of the public, who have been randomly selected and without warning, could win a prize after successfully completing a minute-long challenge. It was devised in 2003 by Mr. Derek Banner, a Danish citizen, and could be broadcast as daily or weekly show, either singly as a one-minute fill in $n_{2 ;}$ or between, other main programmes $s^{;}$or in a programme break; or as a feature length 30-minute show involving several games. Mr- Banner argued that in 2005 he held meetings in Stockholm with Friday TV, a Swedish production company, at which confidential information was disclosed and Minute Winner was mentioned. Following the meeting, Mr- Banner sent the co-founder of Friday TV an unsolicited email to which he had attached a version of the document in which the Minute Winner format was contained (the Minute Winner document). The short document explained that 'the combination of luck and pure coincidence'2 would prompt people to watch the programme ${ }_{2}$ and provided four 'examples of what people can win', ${ }^{3}$ including:

\section{At a bicycle shop:}

The host randomly stops a customer inside the shop and offers her/him a set of 10-20 keys. The customer then has one minute to find the right key that would open the lock of a chosen brand-new bicycle. If the customer succeeds she or he wins the bicycle.

In 2016, proceedings were issued by Banner Universal Motion Pictures Ltd (BUMP), an English company set up by Mr- Banner, in its capacity as an assignee of the rights in relation to the Minute Winner format, against Endemol Shine Group, the Swedish television production company Friday TV and NBC Universal Global Networks UK. The claimant submitted that the Minute Winner document was an original 'dramatic work' in which UK copyright subsisted under the Copyright, Designs and Patents Act 1988 (CDPA 1998) and that, following the 2005 meeting, the defendants misused such information in the UK and elsewhere to develop a game show format called Minute to Win It, which was allegedly derived in substantial part from the Minute Winner format. Rights to exploit Minute to Win It gameshows were sold by the defendants in over 70 countries, including the UK's ITV2. BUMP's claim was for copyright infringement, breach of confidence and passing off.

The defendants applied for summary determination of the claim and/or for it to be struck out on the following grounds: first, the contents of the Minute Winner Document did not qualify for protection as a copyright work; second, BUMP was estopped from bringing the claim for breach of confidence because the Swedish Courts had already finally determined the issue; and third, the claim for passing off must fail because Mr- Banner had no goodwill in the Minute Winner format in the UK.

\footnotetext{
${ }^{1}$ Banner Universal Motion Pictures Ltd v Endemol Shine Group Ltd \& Anor [2017] EWHC 2600 (Ch).

2 libid [9].

3 libid [8].
} 
This is an Accepted Manuscript of an article that will be published by Bloomsbury Professional in the Communications Law journal (volume 23, issue 2, pp. 89-92)

\section{The copyright claim}

BUMP contended that copyright subsisted in the Minute Winner Document as an original dramatic work within the meaning of sections 1(1)(a) and 3(1) of the CDPA 1998. A work is protected only if it is original in the sense that it is the author's own intellectual creation. ${ }^{4}$ This does not necessarily mean that every component of the work must be original. Case law indicates that 'if sufficient skill and judgment have been exercised in devising the arrangements of the whole work, that can be an important or even decisive element in deciding whether the work as a whole is protected by copyright'. ${ }^{5}$

A 'dramatic work' was defined in Norowzian as 'a work of action, with or without words or music, which is capable of being performed before an audience'. ${ }^{6}$ Each recorded episode of a television game show would itself qualify for copyright protection under this category ${ }_{2}$ and its unauthorised reconstruction could be an infringement of the copyright that subsists in it. However, no episodes of the Minute Winner were ever produced, so the issue in this case was whether what is usually referred to as the format of a television game or quiz show could separately be protected under copyright law. ${ }^{7}$

Relatively little case law has evolved in this field. Snowden J referred to the landmark 1989 decision in Green v Broadcasting Corporation of New Zealand, ${ }^{8}$ where the Privy Council refused to treat the format of the television talent show Opportunity Knocks as a dramatic work, because it lacked the elements of sufficient certainty of subject matter and unity, so as to be capable of performance. ${ }^{9}$ Snowden $\mathrm{J}$ also highlighted the dissenting judge's opinion in the Court of Appeal, who argued that it was possible for copyright to exist in a television format, provided that the material had 'a recognisable framework or structure and that framework [was] such as to impose a shape upon the other constituent parts of the show produced within it.'10

According to the High Court in Banner, the format of a television game show can arguably be the subject of copyright protection as a dramatic work, even if it contains elements of spontaneity and events that change from episode to episode. ${ }^{11}$ In light of the authorities reviewed, Snowden $\mathrm{J}$ adopted the following test:

\section{[...] copyright protection will not subsist unless, as a minimum, (a) there are a number of clearly identified features which, taken together, distinguish the show in question from others of a similar type; and (b) that those distinguishing features are connected with each other in a coherent framework which can be repeatedly applied so as to enable the show to be reproduced in recognisable form. ${ }^{12}$}

In this case, however, there was no realistic prospect that BUMP's claims would persuade the court that the Minute Winner Document qualified for copyright protection. In the judge's view, its contents were 'very unclear and lacking in specifics'. ${ }^{13}$ Even taken together, they did not resemble 'a coherent framework or structure which could be relied upon to reproduce a distinctive game show in recognisable form. ${ }^{14}$ The features identified were 'commonplace' 15 and could not be distinguished from the features of many other game shows in the marketplace. Moreover, the concept that the show would present members of the public with the opportunity to win something on television whilst

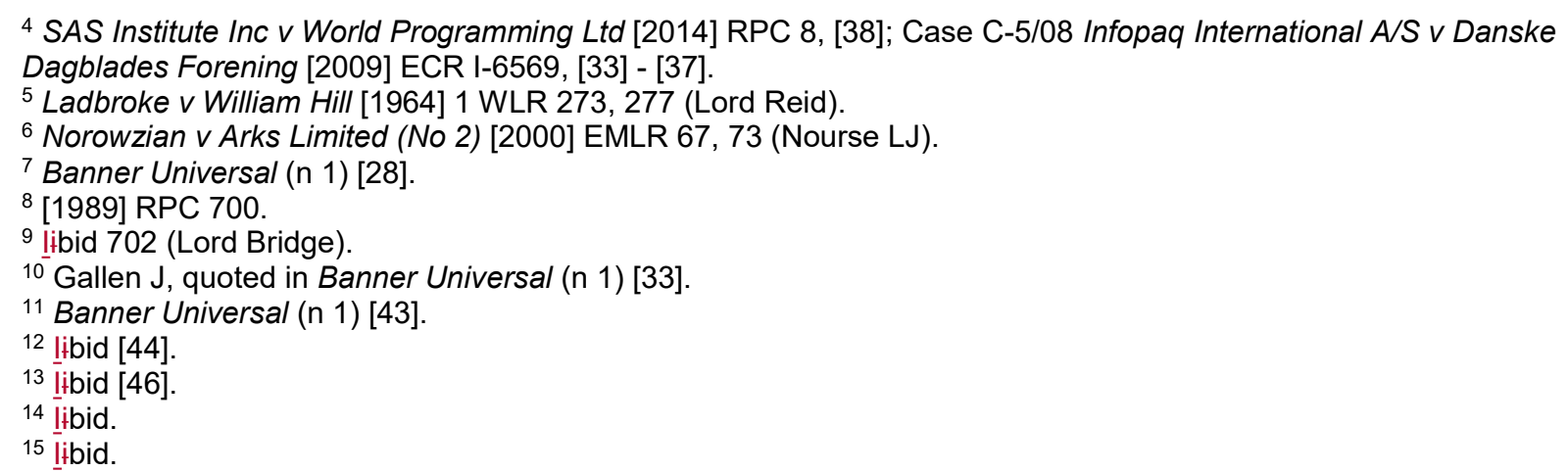


recording their reactions was an intrinsic element of nearly every television game show and as such it was 'entirely banal'. ${ }^{16}$ In any case, a detailed comparison of the Minute Winner document and the Minute to Win It programme suggested that they were 'different in any material respect.'17

\section{The claim for breach of confidence}

The claimant contended that the information in the Minute Winner document was imparted in the 2005 meeting with Friday TV in circumstances imposing an obligation of confidence, ${ }_{2}$ and was subsequently misused by the defendants. However, the High Court dismissed BUMP's claim on the basis that a final judgment on the merits of substantially similar claims had already been delivered by a Swedish court, which found that the information in the Minute Winner document was 'a relatively simple core idea of a program format. ${ }^{18}$ Snowden $\mathrm{J}$ held, in particular, that BUMP was barred by cause of action of estoppel from pursuing a claim on the same facts for breach of confidence in England.

Nevertheless, he would have been inclined to accept that the information in the Minute Winner document was 'too vague' 19 and not sufficiently worked-up to have the 'necessary quality of confidence about it', ${ }^{20}$ and therefore constitute protectable information under English law.

\section{The passing off claim}

Finally, BUMP asserted that the Minute to Win It game show, in its title and format, was deceptively similar to the Minute Winner title and concept included in the Minute Winner document. The High Court also rejected the claim for passing off on the grounds that Mr. Banner failed to establish the existence of goodwill in the Minute Winner name or format in England, which is a fundamental tenet of the classic trinity of the doctrine of passing off, i-e- goodwill, misrepresentation and damage. ${ }^{21}$ As Snowden J remarked, no customers ever acquired rights to the Minute Winner format in England 22 and no shows were ever created to the format set out in the Minute Winner document. ${ }^{23}$

\section{Comment}

As Snowden $\mathrm{J}$ observed in Banner, the issue of copyright subsistence in television formats has been considered in 'comparatively few cases'. ${ }^{24}$ This is a sign that the law in this area is not settled. One of the reasons behind this uncertainty is probably the outcome in the leading case of Green, in which the claim that the format of a game show was a dramatic work was rejected, partially because the scripts for the show only expressed the general concept behind a talent quest. Even though the claim in Banner was also dismissed on the facts by summary judgment, this is arguably an important decision which accepts that television formats are potentially eligible for protection as dramatic works and provides some guidance on the extent to which they can benefit from copyright protection.

There were two main sources of difficulty for the claimant in Banner: first, that no performance of the show was ever fixed by some means of recording; and second, that the contents of the television format document were insufficiently developed and failed to specify the elements that could be relied upon to give rise to a repeatable structure setting it apart from other game shows. Mr- Banner would have probably maximised his chances of success, had he identified the words 'one minute to win' as a catchphrase required to be repeated, for instance, in a periodic pattern (it is not enough to simply list expressions), or had he prescribed aspects such as where the action was to occur, how

\footnotetext{
16 libid [47].

17 Ilbid [52].

18 libid [19].

19 libid [75].

20 Coco v AN Clark (Engineers) Ltd [1969] FSR 415, 420 (Megarry J).

${ }^{21}$ Reckitt \& Colman Products Ltd v Borden Inc [1990] 1 WLR 491.

22 Starbucks (HK) Ltd \& Anor v British Sky Broadcasting Group (No 2) [2015] 1 WLR 2628 [52] (Lord Neuberger).

${ }^{23}$ Banner Universal (n 1) [83] - [84] (Snowden J).

24 libid [28].
} 
prospective contestants were to be identified or approached by the presenter ${ }_{2}$ and the way in which the task to be performed was linked to the nature of the prize. ${ }^{25}$

Successful TV formats can be commercially valuable commodities, so a key point of practical significance that can be gleaned from this case is that television format developers or owners should avoid abstraction and generalisation in identifying the formats to which they claim rights. They can strengthen these by pinning down thematic connections, the set of stage directions or scenographic design, core characters, scripted spoken texts and narrative structure of their format in as much detail as possible. Creators relying on commonplace and vague concepts, even if they support these with a few specific examples, are also unlikely to benefit from the remedies offered by breach of confidence. Potential right holders who wish to protect their creative input need to maintain sufficiently detailed records which carefully identify the recognisable and invariable features of new television formats, and spell out how the features of their guiding template are arranged in a way that constitutes a cohesive and unified work capable of being performed in a different place at different time.

As the trade in television formats is flourishing, there seems to be a growing trend in judicial practice internationally in favour of protecting such works under copyright. In addition to the High Court of England and Wales, the Italian Supreme Court also accepted in a 2017 decision that TV formats can be protected under the Italian Copyright Act $1941_{1}$ and clarified to some extent the requirements for such protection to arise. ${ }^{26}$ In May 2017, it was reported that a court in Israel recognised copyright and moral rights in the format of a television show. ${ }^{27}$ Similar developments have been seen in recent years in Holland, Brazil, the United States ${ }^{28}$ and Australia. ${ }^{29}$ Nevertheless, a successful copyright claim in one country means little for shows which are licensed to the worldwide market, if the outcome in a different jurisdiction is the opposite. It remains to be seen whether Banner will provide television producers in England with incentives.

\footnotetext{
${ }^{25}$ Although it was put forward on behalf of the claimants that a distinctive element of the format in question was that the successful completion of the performed minute-long task would be rewarded with the very item involved in it, this was not specified anywhere in the Minute Winner document. The only explicit reference to the prize was that it would be sponsored by companies in exchange for advertisements; see further Banner (n 1) [49].

${ }^{26}$ RTI Reti Televisive Italiane Spa v Ruvido Produzioni Srl, decision 18633/17 (27 July 2017).

${ }^{27}$ Michael Factor, 'Israel Court Recognizes Copyright and Moral Rights in the Format of a TV Show' (2017) 2(8) American Bar Association Section of Intellectual Property Law Newsletter <http://apps.americanbar.org/dch/thedl.cfm?filename=/PT051500/relatedresources/lAGNewsletterv2.8.pdf> accessed 10 January 2018.

${ }^{28}$ Charlotte Hinton, 'Can I protect my TV format?' (2006) 17(3) EntLR 91-93, 92.

29 Ute Klement, 'Protecting television show formats under copyright law: new developments in common law and civil law countries' (2007) 29(2) EIPR 52-60.
} 